Article

\title{
Cobalt/iron bimetal-organic frameworks as efficient electrocatalysts for the oxygen evolution reaction
}

\author{
Shili Xie a, Fei Li a,*, Suxian Xu a, Jiayuan Li a, Wei Zeng b,\# \\ a State Key Laboratory of Fine Chemicals, Dalian University of Technology, Dalian 116024, Liaoning, China \\ b Dalian Wondersun Biochemical Technology Co., LTD, Dalian 116600, Liaoning, China
}

A R T I C L E I N F

Article history:

Received 14 March 2019

Accepted 19 April 2019

Published 5 August 2019

\section{Keywords:}

Bimetal-organic frameworks

Oxygen evolution reaction

Electrocatalysts

Synergetic effect

Ultrasonic method

\begin{abstract}
A B S T R A C T
The development of high efficiency and stable electrocatalysts for oxygen evolution is critical for energy storage and conversion systems. Herein, a series of $\mathrm{Co} / \mathrm{Fe}$ bimetal-organic frameworks (MOFs) were fabricated using a facile ultrasonic method at room temperature, as electrocatalysts for the oxygen evolution reaction (OER) in alkaline solution. The $\mathrm{Co}_{2} \mathrm{Fe}-\mathrm{MOF}$ exhibited an overpotential of $280 \mathrm{mV}$ at a current density of $10 \mathrm{~mA} \mathrm{~cm}{ }^{-2}$, a low Tafel slope of $44.7 \mathrm{mV} \mathrm{dec}^{-1}$, and long-term stability over $12000 \mathrm{~s}$ in $1 \mathrm{~mol} \mathrm{~L}^{-1} \mathrm{KOH}$. This impressive performance was attributed to the high charge transfer rate, large specific surface area, and synergistic effects of the cobalt and iron centers.
\end{abstract}

(C) 2019, Dalian Institute of Chemical Physics, Chinese Academy of Sciences. Published by Elsevier B.V. All rights reserved.

\section{Introduction}

The energy crisis and environmental pollution are serious issues caused by the continuous consumption of fossil fuels [1]. Developing renewable and clean sources of energy to replace traditional fossil fuels has become increasingly necessary [2-4]. Hydrogen production via electrochemical water splitting is considered to be an ideal method to solve these issues. The oxygen evolution reaction (OER) is a bottleneck for overall water splitting due to its sluggish reaction kinetics [5-7]. Therefore, efficient electrocatalysts should be developed for the OER to decrease the overpotential and increase the reaction rate. Although some state-of-the-art noble metal catalysts (e.g., $\mathrm{IrO}_{2}$ or $\mathrm{RuO}_{2}$ ) exhibit high electrocatalytic performance, their high cost and scarcity prohibit large-scale application $[2,8,9]$. Therefore, significant efforts have been devoted to developing low cost and earth-abundant electrocatalysts, including non-noble transition metal-based oxides [10], (oxy)hydroxides [11,12], phosphides [13-15], nitrides [16], sulfides [17-20], and selenides [21-23]. Among them, Co-based materials have exhibited promising performance for the OER because oxidized cobalt centers can promote the formation of $\mathrm{OOH}$ species and subsequent deprotonation to form $\mathrm{O}_{2}$ [24]. In addition, when $\mathrm{Fe}$ is doped into Co-based catalysts, the OER performance can be further improved [25,26].

Metal-organic frameworks (MOFs), also known as porous coordination polymers, have been widely applied to medicine delivery [27], gas storage and separation [28,29], catalysis [30], and sensing [31] due to their large specific surface areas, tunable pore sizes, periodic structures, and diversity of metal centers and organic linkers. For electrochemical water splitting, MOFs have been used as precursors and templates for synthe-

\footnotetext{
*Corresponding author. Tel: +86-411-84986247; Fax: +86-411-84986245; E-mail: lifei@dlut.edu.cn

\# Corresponding author. Tel: +86-411-88165993; Fax: +86-411-88165911; E-mail: zeng_wei@wdspharma.com

This work was supported by the National Natural Science Foundation of China (21872016), and the Fundamental Research Funds for the Central Universities (DUT17ZD204).

DOI: S1872-2067(19)63384-X | http://www.sciencedirect.com/science/journal/18722067 | Chin. J. Catal., Vol. 40, No. 8, August 2019
} 
sizing oxide/carbon composites with high OER activity [32-35]. However, tedious fabrication processes and high pyrolysis temperatures are generally required, which is unsuitable for practical applications. Consequently, the direct use of MOFs as electrocatalysts toward OER is desirable.

Herein, we report a facile ultrasonic method for fabricating Co/Fe-based bimetal-organic frameworks as highly efficient water oxidation catalysts in alkaline solution. The OER performance of the Cox $\mathrm{Fe}-\mathrm{MOFs}$ followed a volcano-type pattern with increasing $\mathrm{Fe}$ content. The optimized $\mathrm{Co}_{x} \mathrm{Fe}-\mathrm{MOF}$ s exhibited high catalytic activity with an overpotential of $280 \mathrm{mV}$ at $10 \mathrm{~mA}$ $\mathrm{cm}^{-2}$ and a Tafel slope of $44.7 \mathrm{mV} \mathrm{dec}^{-1}$. This performance can be ascribed to the large specific surface area, excellent conductivity, and synergistic effects of Co and Fe.

\section{Experimental}

\subsection{Materials}

$\mathrm{CoCl}_{2} \cdot 6 \mathrm{H}_{2} \mathrm{O}$ was purchased from Tianjin Guangfu Technology Development Co., Ltd. $\mathrm{FeCl}_{3} \cdot 6 \mathrm{H}_{2} \mathrm{O}$, trimesic acid ( $\mathrm{H}_{3} \mathrm{BTC}$ ), and $\mathrm{RuO}_{2}$ were purchased from Aladdin. Triethylamine $\left(\left(\mathrm{C}_{2} \mathrm{H}_{5}\right)_{3} \mathrm{~N}\right)$ and $N, N$-dimethylformamide (DMF) were purchased from Tianjin Fuyu Fine Chemical Co. Nafion (5\%) was obtained from Sigma Aldrich. All reagents were used without further purification, and deionized water was used throughout the experiments.

\subsection{Synthesis of the $\mathrm{Co}_{x} \mathrm{Fe}-\mathrm{MOFS}$}

The $\mathrm{Co}_{x} \mathrm{Fe}-\mathrm{MOF}$ s were synthesized according to a previously reported method with some modifications [36]. In a typical synthesis, $\mathrm{H}_{3} \mathrm{BTC}(0.75 \mathrm{mmol}), \mathrm{CoCl}_{2} \cdot 6 \mathrm{H}_{2} \mathrm{O}$ ( $\left.0.5 \mathrm{mmol}\right)$, and $\mathrm{FeCl}_{3} \cdot 6 \mathrm{H}_{2} \mathrm{O}(0.25 \mathrm{mmol})$ were dissolved in a mixed solution of DMF (32 mL), ethanol $(2 \mathrm{~mL})$, and deionized water $(2 \mathrm{~mL})$ under vigorous stirring. Subsequently, triethylamine $(0.8 \mathrm{~mL})$ was added rapidly to the above solution. The mixture was stirred for $5 \mathrm{~min}$ and continuously ultrasonicated for $8 \mathrm{~h}$ at room temperature. Finally, the products were collected via centrifugation, washed with ethanol three times, and dried at $60{ }^{\circ} \mathrm{C}$ overnight. A similar procedure was adopted for the preparation of the $\mathrm{Co}_{-}, \mathrm{Co}_{3} \mathrm{Fe}-$, $\mathrm{Co}_{1} \mathrm{Fe}-$, and Fe-MOFs using different molar ratios of $\mathrm{Co} / \mathrm{Fe}$ chloride salts $(1: 0,3: 1,1: 1,0: 1)$ at the beginning with the total amount of metal salt held constant at $0.75 \mathrm{mmol}$.

\subsection{Characterization}

Field-emission scanning electron microscopy (FESEM) was performed using a NOVA NanoSEM 450 instrument at $10 \mathrm{kV}$. Transmission electron microscopy (TEM), HRTEM, and EDS were performed using a JEM2100F TEM instrument at an acceleration voltage of $200 \mathrm{kV}$. X-ray diffraction (XRD) was performed using a D/max-2400 diffractometer with $\mathrm{Cu} K_{\alpha}$ radiation $(\lambda=154.1 \mathrm{~nm})$. X-ray photoelectron spectroscopy (XPS) was recorded on an ESCALAB 250Xi spectrometer with a monochromated $\mathrm{Al} K_{\alpha}$ radiation source. Fourier transform infrared spectra (FT-IR) were collected using a NEXUS EURO instru- ment. Inductively coupled plasma-atomic emission spectrometry (ICP-AES) was performed with an Optima2000DV instrument from PerkinElmer company. The BET specific surface area was determined using an AUTO SORB-1-MP apparatus.

\subsection{Electrochemical measurements}

To prepare the working electrode, $5 \mathrm{mg}$ of the prepared catalysts were added into a mixed solution containing $480 \mu \mathrm{L}$ of water, $480 \mu \mathrm{L}$ of ethanol, and $40 \mu \mathrm{L}$ of a $5 \%$ Nafion solution. Subsequently, the mixed solution was sonicated for $30 \mathrm{~min}$ to obtain a homogeneous catalyst ink. Finally, $5 \mu \mathrm{L}$ of the catalyst ink was immobilized on glassy carbon by drop-casting and dried at room temperature. All electrochemical measurements were performed using a standard three-electrode system (CHI $760 \mathrm{E}$ electrochemical station) at room temperature. The electrolyte was a $1 \mathrm{~mol} \mathrm{~L}^{-1} \mathrm{KOH}$ solution. A glass carbon electrode was utilized as the working electrode, and $\mathrm{Hg} / \mathrm{HgO}$ and Pt wire were used as the reference and counter electrodes, respectively. All potentials were calibrated to the reversible hydrogen electrode (RHE) using the following equation: $E$ (RHE) = $E(\mathrm{Hg} / \mathrm{HgO})+0.098 \mathrm{~V}+0.059 \mathrm{PH}$. Linear sweep voltammetry (LSV) was recorded at a scan rate of $5 \mathrm{mV} \mathrm{s}^{-1}$ with $95 \%$ iR-compensation. Electrochemical impedance spectroscopy (EIS) was performed at a frequency ranging from $10 \mathrm{kHz}$ to 0.1 $\mathrm{Hz}$ at $1.53 \mathrm{~V}$ vs. RHE. The durability test was conducted by cyclic voltammetry (CV) from 1.1 to $1.7 \mathrm{~V}$ vs. RHE at a scan rate of $100 \mathrm{mV} \mathrm{s}^{-1}$ for 500 cycles. The chronopotentiometry was measured at a current density of $10 \mathrm{~mA} \mathrm{~cm}^{-2}$. To estimate the electrochemical active surface area (ECSA) of the catalyst, the electrochemical double layer capacitance $(C \mathrm{dl})$ was measured via $\mathrm{CV}$ in the non-Faradaic potential range of 0.1 to $0.2 \mathrm{~V}$ vs. $\mathrm{Hg} / \mathrm{HgO}$ with scan rates of $10-50 \mathrm{mV} \mathrm{s}^{-1}$. The turnover frequency (TOF) was calculated using the following formula: TOF $=j A / 4 n F$, where $j$ is the current density at an overpotential of $280 \mathrm{mV}, A$ is the geometric area of the GC electrode, 4 is the number of electrons transferred to produce one molecule of oxygen, $n$ is the number of moles of active sites, and $F$ is Faraday constant $\left(96485 \mathrm{C} \mathrm{mol}^{-1}\right)$.

\section{Results and discussion}

The fabrication process of the $\mathrm{Co}_{x} \mathrm{Fe}-\mathrm{MOFs}$ is illustrated in Scheme 1. Triethylamine was used to accelerate the deprotonation of the organic ligands under ultrasonic conditions [37]. The $\mathrm{Co}_{x} \mathrm{Fe}-\mathrm{MOF}$ were formed by the coordination reaction of $\mathrm{Co}^{2+} / \mathrm{Fe}^{3+}$ with deprotonated trimesic acid $\left(\mathrm{H}_{3} \mathrm{BTC}\right)$. The structural information of the as-prepared Co-, $\mathrm{Co}_{x} \mathrm{Fe}-$, and Fe-MOFs was obtained by XRD, as shown in Fig. 1a. With increasing Fe content, the crystal structure of the $\mathrm{Co}_{x} \mathrm{Fe}-\mathrm{MOF}$ gradually changed from Co-MOF to Fe-MOF. FT-IR spectroscopy was performed to characterize the functional groups in the $\mathrm{Co}_{2} \mathrm{Fe}-\mathrm{MOF}$ (Fig. 1b). The free trimesic acid ligand was also analyzed by FT-IR for comparison. In the $\mathrm{Co}_{2} \mathrm{Fe}-\mathrm{MOF}$, the absorption band at $3426 \mathrm{~cm}^{-1}$ was attributed to the stretching vibration of the $\mathrm{O}-\mathrm{H}$ motifs. The bands between 1300 and 1650 $\mathrm{cm}^{-1}$ arose from the stretching vibrations of $\mathrm{C}=\mathrm{O}$ and $\mathrm{C}-\mathrm{C}$ 


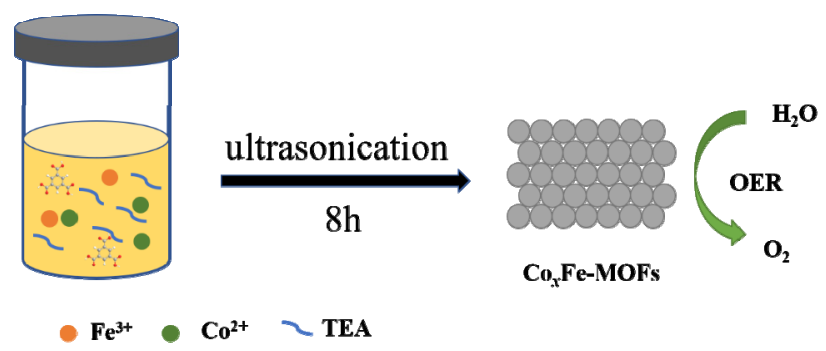

Scheme 1. Schematic illustration of the fabrication procedure of the $\mathrm{Co}_{x} \mathrm{Fe}-\mathrm{MOFs}$.

bonds, respectively, on the benzene rings [38]. In particular, the bands at 1622 and $1371 \mathrm{~cm}^{-1}$ can be ascribed to the respective asymmetric and symmetric stretching vibration bands of the carboxyl groups bound to metal ions. For comparison, the free trimesic acid ligand showed a stretching vibration of the carboxyl group at $1721 \mathrm{~cm}^{-1}$. The difference in asymmetric vibration indicates that no free carboxylic groups were present in Co2Fe-MOF [39].

The morphology and microstructure of $\mathrm{Co}_{2} \mathrm{Fe}-\mathrm{MOF}$ were characterized by SEM and TEM. The SEM images (Fig. 2a and $2 \mathrm{~b}$ ) indicate that $\mathrm{Co}_{2} \mathrm{Fe}-\mathrm{MOF}$ is composed of nanoparticles with an average size of approximately $50-100 \mathrm{~nm}$. These nanoparticles were loosely packed into a porous structure, which is favorable for exposing more active sites for the OER. In the high-resolution TEM image of $\mathrm{Co}_{2} \mathrm{Fe}-\mathrm{MOF}$ (Fig. 2d), no obvious lattice fringes were observed due to the easily damaged MOF structure under high energy electron beam irradiation [40]. This result is consistent with the observation of weak circle rings shown at the top-right selected area electron diffraction (SAED) pattern. As shown by high-angle annular dark-field scanning transmission electron microscopy (HAADF-STEM; Fig. $2 \mathrm{e}$ ), the EDS element mapping revealed a uniform distribution of $\mathrm{Co}, \mathrm{Fe}, \mathrm{C}$, and $\mathrm{O}$ throughout the entire catalyst without impurities. EDS elemental analysis confirmed a molar ratio of 2:1 for Co: Fe (Fig. S1), consistent with the inductively coupled plasma (ICP) analysis (Table S1).

XPS measurements were obtained to investigate the surface composition and chemical valance states of the as-obtained $\mathrm{Co} 2 \mathrm{Fe}-\mathrm{MOF}$. The XPS survey spectra verified the coexistence of
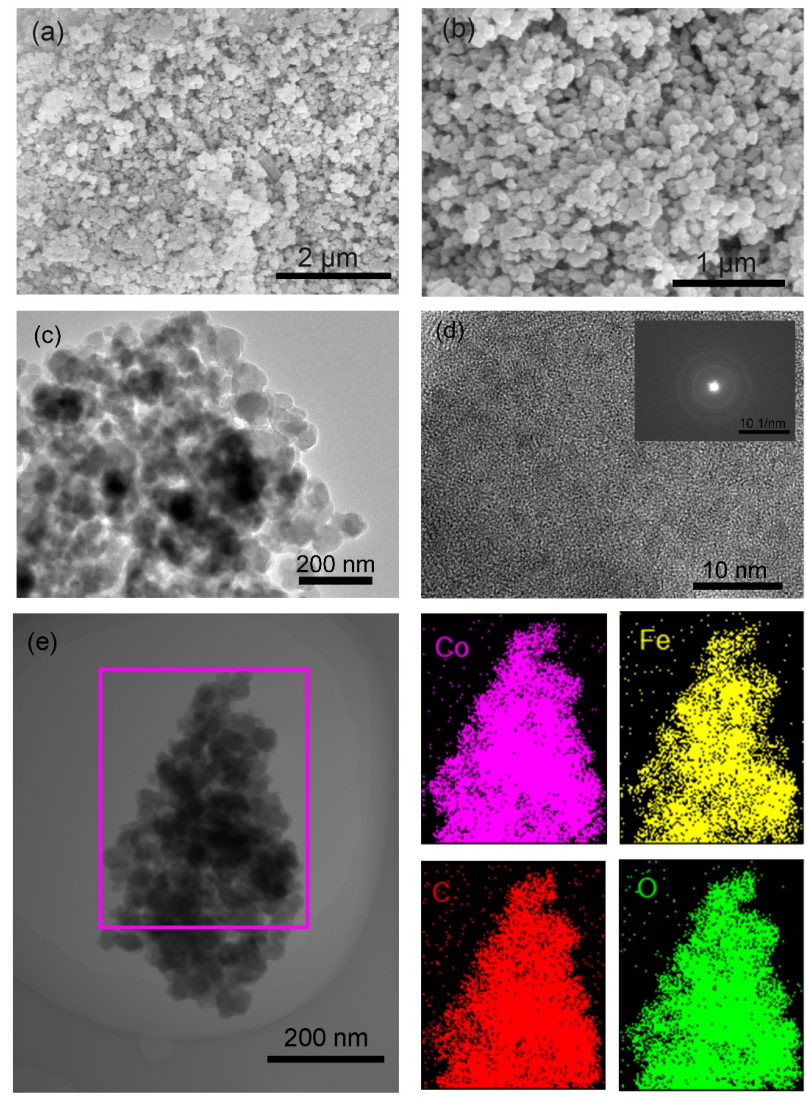

Fig. 2. (a, b) SEM images of $\mathrm{Co}_{2} \mathrm{Fe}-\mathrm{MOF}$. (c) TEM and (d) HRTEM images (inset: SAED pattern) of $\mathrm{Co}_{2} \mathrm{Fe}-\mathrm{MOF}$; (e) HAADF-STEM image and STEM-EDS element mapping of $\mathrm{Co}_{2} \mathrm{Fe}-\mathrm{MOF}$ (Co: pink; Fe: yellow; C: red; O green).

Co, Fe, C, and O (Fig. S2). In the Co $2 p$ region (Fig. 3a), the binding energies of 781.9 and $797.7 \mathrm{eV}$ can be ascribed to Co $2 p_{3 / 2}$ and $2 p_{1 / 2}$ peaks, respectively. In addition, two satellite peaks corresponding to Co $2 p_{3 / 2}$ and Co $2 p_{1 / 2}$ were observed at 786.5 and $803.2 \mathrm{eV}$, respectively. These results suggest the presence of $\mathrm{Co}^{2+}$ bound to oxygen [41]. The Fe $2 p$ region shown in Fig. $3 \mathrm{~b}$ exhibited two peaks at 711.5 and $725.3 \mathrm{eV}$, which were assigned to Fe $2 p_{3 / 2}$ and Fe $2 p_{1 / 2}$, respectively. Moreover, a satellite peak at $716.2 \mathrm{eV}$ was observed, indicating the +3 valance
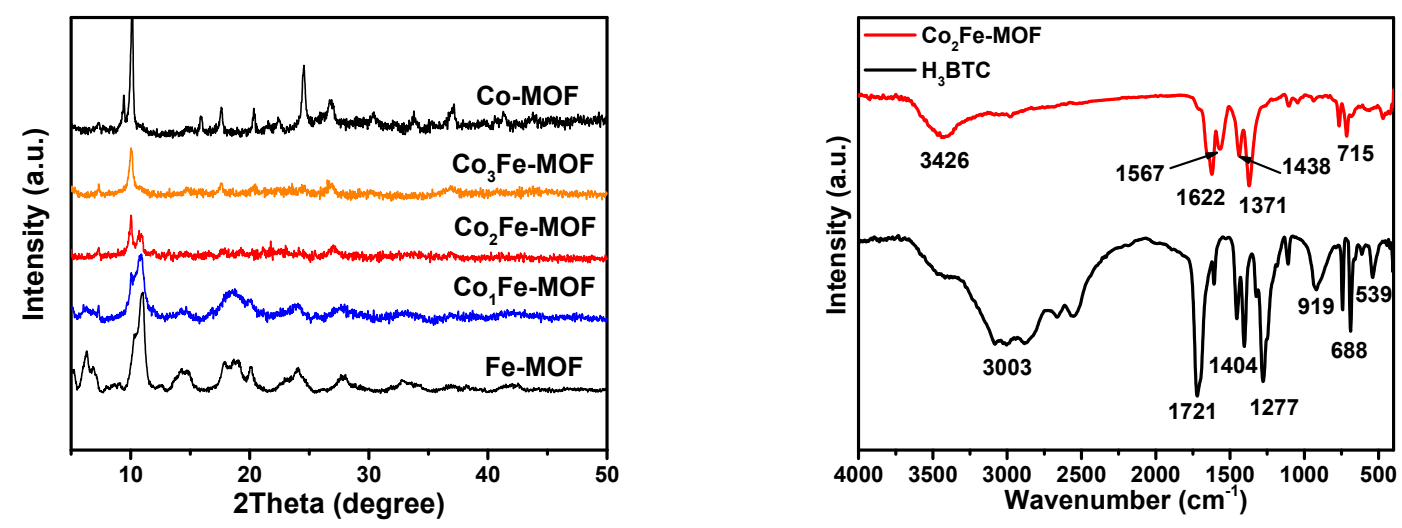

Fig. 1. (a) XRD patterns of the Co-MOF, $\mathrm{Co}_{x} \mathrm{Fe}-\mathrm{MOF}$, and Fe-MOF samples; (b) FT-IR spectra of $\mathrm{Co}_{2} \mathrm{Fe}-\mathrm{MOF}$ and $\mathrm{H}_{3} \mathrm{BTC}$. 

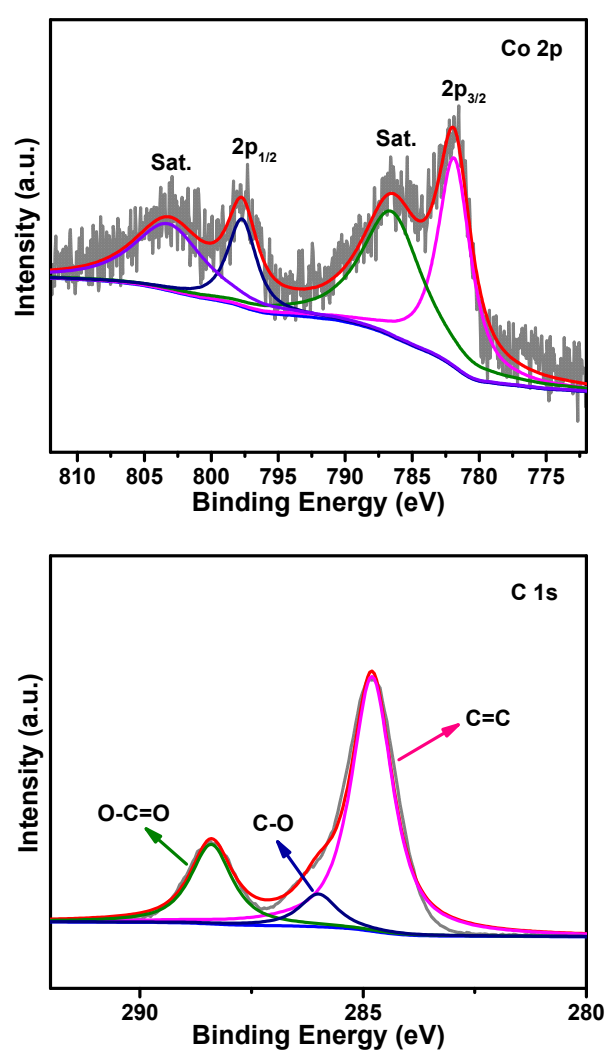
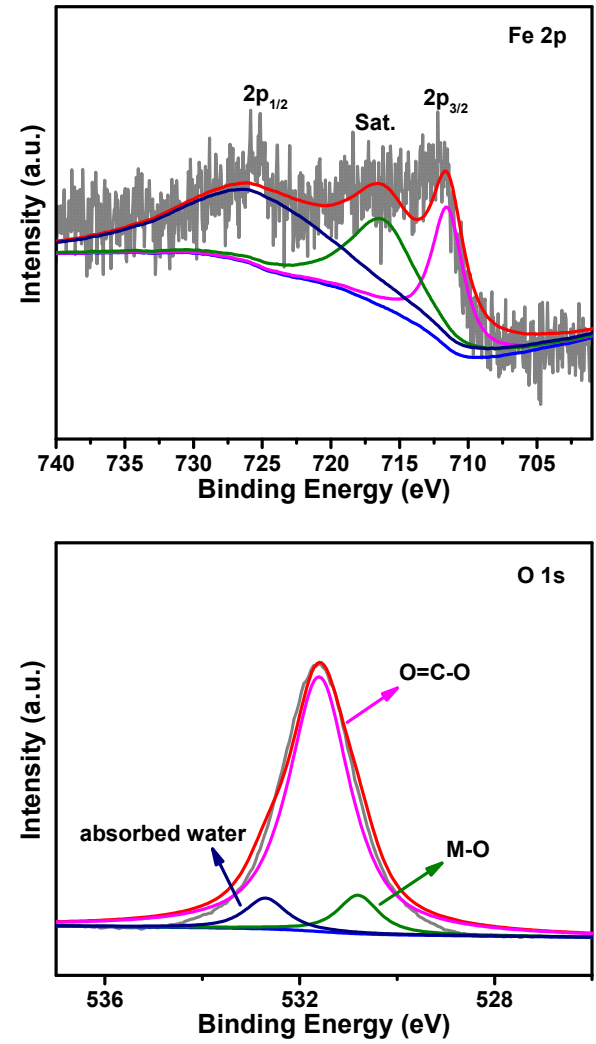

Fig. 3. (a-d) High-resolution XPS spectra of Co $2 p$, Fe $2 p, \mathrm{C} 1 s$, and $\mathrm{O} 1 s$ for the $\mathrm{Co}_{2} \mathrm{Fe}-\mathrm{MOF}$ electrocatalyst.

state for iron [42]. The C $1 s$ spectrum was deconvoluted into three peaks (Fig. 3c). The peak at $284.8 \mathrm{eV}$ was attributed to $\mathrm{C}=\mathrm{C}$ bond of the benzoic ring, the $288.4 \mathrm{eV}$ peak arose from the carboxyl group $(\mathrm{O}=\mathrm{C}-\mathrm{O})$ of $\mathrm{BTC}^{3-}$, and the $286.0 \mathrm{eV}$ peak was assigned to $\mathrm{C}-\mathrm{O}[39,43]$. In the high-resolution XPS spectrum of $01 s$ (Fig. 3d), three peaks at 530.8, 531.6 and $532.7 \mathrm{eV}$ were observed, arising from the coordinated oxygen, carbonyl group, and absorbed water, respectively [39]. Compared to those of the Co-MOF, the binding energies of the Co $2 p_{3 / 2}$ and Co $2 p_{1 / 2}$ spectra of $\mathrm{Co}_{2} \mathrm{Fe}-\mathrm{MOF}$ were positively shifted by $0.3 \mathrm{eV}$, indicating decreasing electron density at the Co centers. Furthermore, the Fe $2 p_{3 / 2}$ and $\mathrm{Fe} 2 p_{1 / 2}$ peaks were negatively shifted by $0.3 \mathrm{eV}$ compared to those of Fe-MOF, suggesting an electron donation effect from Co to Fe (Fig. S3). The above results indicate that Fe incorporation can regulate the electronic environment of the Co centers. $\mathrm{N}_{2}$ adsorption-desorption isotherms were recorded to calculate the specific surface area of $\mathrm{Co}_{2} \mathrm{Fe}-\mathrm{MOF}$ (Fig. S4). A IV-type isotherm with H3-type hysteresis loop indicated the existence of mesopores in $\mathrm{Co}_{2} \mathrm{Fe}-\mathrm{MOF}$ [44]. The specific surface area of $\mathrm{Co}_{2} \mathrm{Fe}-\mathrm{MOF}$ was determined to be $36.6 \mathrm{~m}^{2} \mathrm{~g}^{-1}$ based on the Brunauer-Emmett-Teller (BET) method. Large surface areas and mesoporous structures are favorable for the improved OER activity.

The electrocatalytic activities of the $\mathrm{Co}_{x} \mathrm{Fe}-\mathrm{MOF}$ toward the OER were evaluated by LSV in a typical three-electrode electrochemical cell with $1 \mathrm{~mol} \mathrm{~L}^{-1} \mathrm{KOH}$ as the electrolyte. A GC electrode with drop-casted catalysts was used as the working electrode and $\mathrm{Hg} / \mathrm{HgO}$ and Pt wire were used as the reference and counter electrodes, respectively. Unless otherwise stated, the ohmic potential drop (iR) arising from solution resistance compensation was applied to all experimental data and all potentials were calibrated against the reversible hydrogen electrode (RHE). For comparison, bare $\mathrm{GC}$ and commercial $\mathrm{RuO}_{2}$ electrodes were tested under the same conditions. As shown in Fig. 4a, the bare GC and Fe-MOF exhibited negligible OER activity. In contrast, the bimetal MOFs showed a significantly enhanced catalytic activity, unlike single metal materials. For the optimized $\mathrm{Co}_{2} \mathrm{Fe}-\mathrm{MOF}$ activity, an overpotential of $280 \mathrm{mV}$ is required to reach a current density of $10 \mathrm{~mA} \mathrm{~cm}-2$, which is lower than those required for $\mathrm{Co}_{1} \mathrm{Fe}-\mathrm{MOF}$ (297 mV), $\mathrm{RuO}_{2}$ (307 $\mathrm{mV}$ ), and $\mathrm{Co}_{3} \mathrm{Fe}-\mathrm{MOF}(314 \mathrm{mV}$ ). This value is also lower than most recently reported Co/Fe-based OER electrocatalysts (Table S2). Meanwhile, $\mathrm{Co}_{2} \mathrm{Fe}-\mathrm{MOF}$ exhibited a lower Tafel slope of $44.7 \mathrm{mV} \mathrm{dec}^{-1}$ than those of the $\mathrm{Co}_{1} \mathrm{Fe}-\mathrm{MOF}$ ( $48.9 \mathrm{mV} \mathrm{dec}^{-1}$ ), Co3 Fe-MOF (55.6 mV dec ${ }^{-1}$ ), Co-MOF (69.9 mV dec ${ }^{-1}$ ), $\mathrm{RuO}_{2}$ (82.0 $\left.\mathrm{mV} \mathrm{dec}^{-1}\right)$, and Fe-MOF (176.2 $\mathrm{mV} \mathrm{dec}^{-1}$ ) samples, reflecting the favorable kinetics of $\mathrm{Co}_{2} \mathrm{Fe}-\mathrm{MOF}$ toward the OER.

EIS analysis was conducted to investigate the electrochemical behavior of the prepared electrodes. The Co2Fe-MOF exhibited a smallest semicircle diameter among these catalysts, as shown in the Nyquist plots (Fig. 4c), indicating that it possessed the lowest charge transfer resistance $\left(R_{\mathrm{ct}}\right)$. Additionally, the ECSAs were evaluated by calculating $C d l$ based on $\mathrm{CV}$ in the non-Faradaic region (Figs. S5 and S6). The $\mathrm{Co}_{2} \mathrm{Fe}-\mathrm{MOF}$ exhibit- 

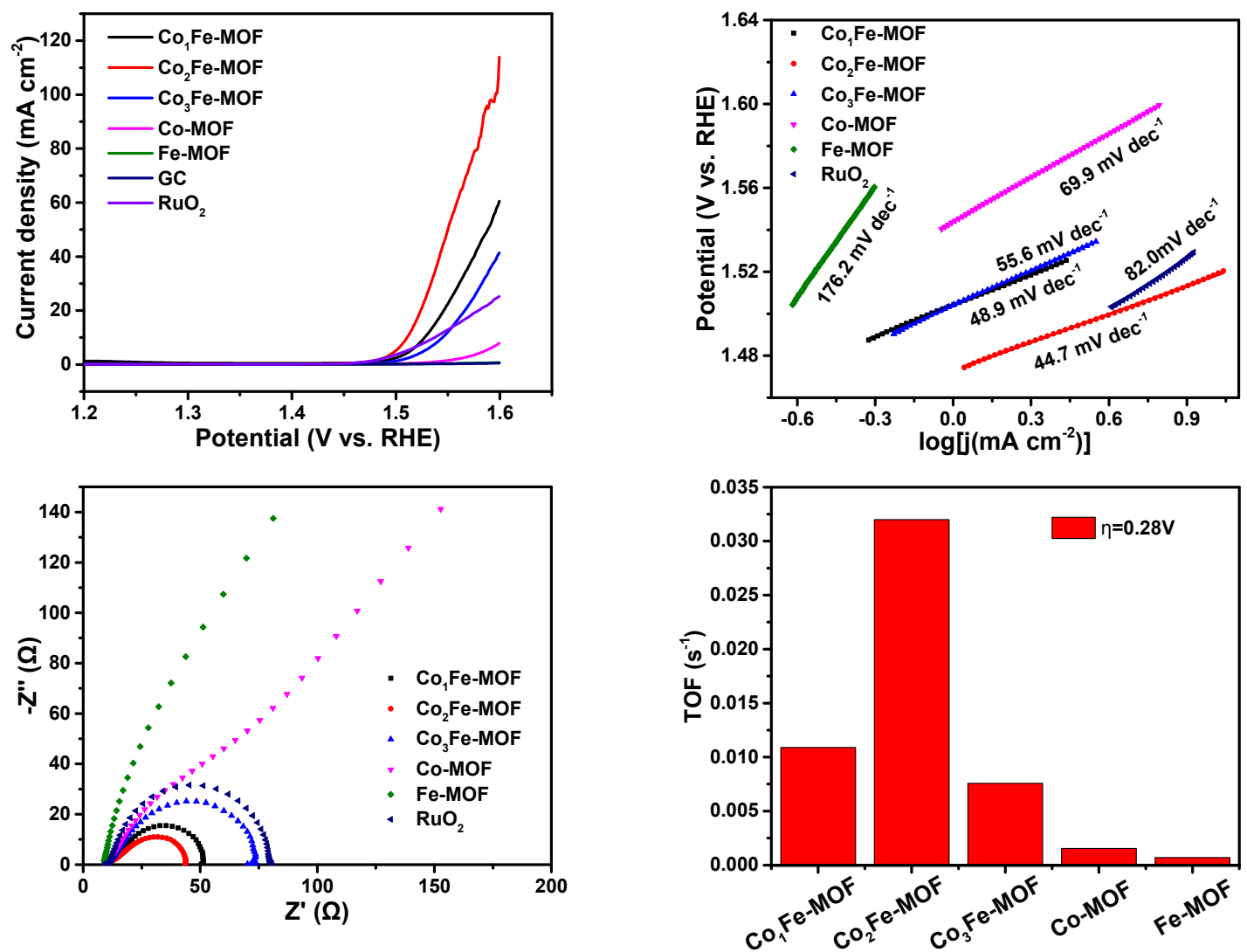

Fig. 4. (a) LSV curves of the $\mathrm{Co}_{x} \mathrm{Fe}-\mathrm{MOFs}$, Co-MOF, Fe-MOF, GC, and $\mathrm{RuO}_{2}$; (b) Tafel plots derived from the LSV curves; (c) Nyquist plots at an overpotential of $300 \mathrm{mV}$; (d) TOF values of the $\mathrm{Co}_{x} \mathrm{Fe}-\mathrm{MOFs}(x=1,2,3)$, Fe-MOF, and Co-MOF at an overpotential of $280 \mathrm{mV}$.

ed a lower Cdl value (2.33 $\left.\mathrm{mF} \mathrm{cm}^{-2}\right)$ compared to those of the Co-MOF (6.28 $\mathrm{mF} \mathrm{cm}^{-2}$ ) and $\mathrm{Co}_{3} \mathrm{Fe}-\mathrm{MOF}\left(3.96 \mathrm{mF} \mathrm{cm}^{-2}\right)$, indicating a superior intrinsic OER activity for the $\mathrm{Co}_{2} \mathrm{Fe}-\mathrm{MOF}$. We further calculate the TOF to evaluate the intrinsic activity of the catalysts. Assuming all $\mathrm{Co}$ and $\mathrm{Fe}$ atoms are involved in the OER, the TOF value of $\mathrm{Co}_{2} \mathrm{Fe}-\mathrm{MOF}$ was $0.032 \mathrm{~s}^{-1}$, higher than those of $\mathrm{Co}_{1} \mathrm{Fe}-\mathrm{MOF}\left(0.011 \mathrm{~s}^{-1}\right)$, Co각e-MOF $\left(0.008 \mathrm{~s}^{-1}\right)$, Co-MOF $\left(0.002 \mathrm{~s}^{-1}\right)$, and Fe-MOF $\left(0.0007 \mathrm{~s}^{-1}\right)$.

Stability is another important parameter for the practical application of electrocatalysts. Fig. 5a shows the LSV curves of the $\mathrm{Co}_{2} \mathrm{Fe}-\mathrm{MOF}$ before and after $500 \mathrm{CV}$ scans at a scan rate of $100 \mathrm{mV} \mathrm{s}^{-1}$. Only slight current density attenuation was observed for the polarization curves after 500 cycles, indicating the superior stability of $\mathrm{Co}_{2} \mathrm{Fe}-\mathrm{MOF}$ for the OER. From the chronopotentiometric curve in Fig. 5b, only a slight increase in the applied potential was required for the $\mathrm{Co}_{2} \mathrm{Fe}-\mathrm{MOF}$ to maintain a current density of $10 \mathrm{~mA} \mathrm{~cm}^{-2}$ for a duration of $12000 \mathrm{~s}$. The $I-t$ curve of the $\mathrm{Co}_{2} \mathrm{Fe}-\mathrm{MOF}$ at an applied potential of $1.58 \mathrm{~V}$ vs. RHE is provided in Fig. S7. The observed slight decrease in catalytic activity was attributed to the oxygen bubble that was
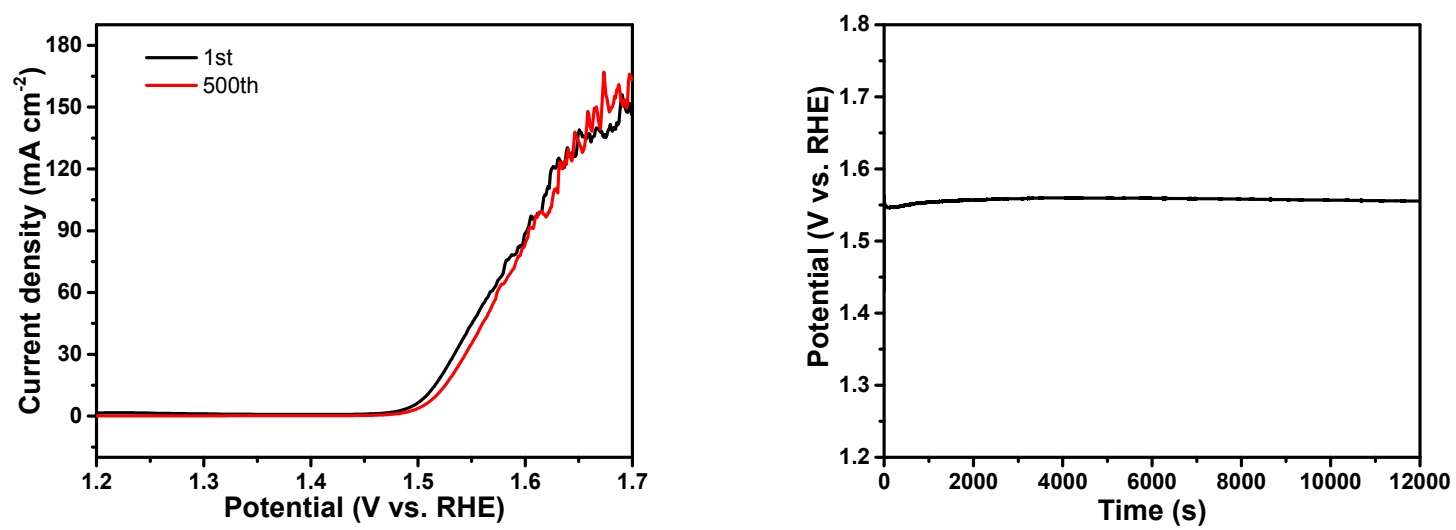

Fig. 5. (a) polarization curves of the $\mathrm{Co}_{2} \mathrm{Fe}-\mathrm{MOF}$ before and after 500 cycles in $1.0 \mathrm{~mol} \mathrm{~L}^{-1} \mathrm{KOH}$; (b) Associated chronopotentiometric curve at a current density of $10 \mathrm{~mA} \mathrm{~cm}^{-2}$. 
adsorbed on the electrode, preventing the intimate contact between the catalyst and electrolyte and detachment of the catalyst from the working electrode surface.

\section{Conclusions}

We synthesized a series of $\mathrm{Co}_{x} \mathrm{Fe}-\mathrm{MOF}$ with different $\mathrm{Co} / \mathrm{Fe}$ molar ratios, using a simple ultrasonic method, as efficient electrocatalysts for the OER. The Co2 Fe-MOF showed the best catalytic performance among the prepared catalysts with a low overpotential of $280 \mathrm{mV}$ at $10 \mathrm{~mA} \mathrm{~cm}{ }^{-2}$ and a Tafel slope of $44.7 \mathrm{mV} \mathrm{dec}^{-1}$. Moreover, the $\mathrm{Co}_{2} \mathrm{Fe}-\mathrm{MOF}$ exhibited long-term durability for at least $12000 \mathrm{~s}$. Its high OER performance can be attributed to the synergistic effects of $\mathrm{Co}^{2+}$ and $\mathrm{Fe}^{3+}$, mesoporous structure, and enhanced charge transfer rate. This study provides a promising method for examining highly active MOF materials for water splitting applications.

\section{References}

[1] X. Q. Du, Z. Yang, Y. Li, Y. Q. Gong, M. Zhao, J. Mater. Chem. A, 2018, 6, 6938-6946.

[2] P. W. Menezes, C. Panda, S. Loos, F. Bunschei-Bruns, C. Walter, M. Schwarze, X. H. Deng, H. Dau, M. Driess, Energy Environ. Sci., 2018, 11,1287-1298.

[3] Y. Gou, Q. Liu, X. F. Shi, A. M. Asiri, J. M. Hu, X. P. Sun, Chem. Commun., 2018, 54, 5066-5069.

[4] Y. N. Guo, J. Tang, Z. L. Wang, Y. M. Kang, Y. Bando, Y. Yamauchi, Nano Energy, 2018, 47, 494-502.

[5] B. Zhang, X. L. Zhang, O. Voznyy, R. Comin, M. Bajdich, M. G. Melchor, L. L. Han, J. X. Xu, M. Liu, L. R. Zheng, F. G. Arquer, C. T. Dinh, F. J. Fan, M. J. Yuan, E. Yassitepe, N. Chen, T. Regier, P. F. Liu, Y. H. Li, P. Luna, A. Janmohamed, H. L. Xin, H. G. Yang, A. Vojvodic, E. H. Sargent, Science, 2016, 352, 333-337.

[6] H. B. Yang, J. W. Miao, S. F. Hung, J. Z. Chen, H. B. Tao, X. Z. Wang, L. P. Zhang, R. Chen, J. J. Gao, H. M. Chen, L. M. Dai, B. Liu, Sci. Adv., 2016, 2, e1501122.

[7] Q. Qin, H. Jang, L. L. Chen, G. Nam, X. E. Liu, J. Cho, Adv. Energy Mater., 2018, 8, 1801478.

[8] K. Xiao, L. Zhou, M. Shao, M. Wei, J. Mater. Chem. A, 2018, 6 , 7585-7591.

[9] C. J. Xuan, J. Wang, W. W. Xia, J. Zhu, Z. K. Peng, K. D. Xia, W. P. Xiao,
H. L. Xin, D. Wang, J. Mater. Chem. A, 2018, 6, 7062-7069.

[10] Z. Li, W. H. Niu, L. Zhou, Y. Yang, ACS Energy Lett., 2018, 3, 892-898.

[11] D. Wu, Y. C. Wei, X. Ren, X. Q. Ji, Y. W. Liu, X. D. Guo, Z. A. Liu, A. M. Asiri, Q. Wei, X. P. Sun, Adv Mater., 2018, 30, 1705366.

[12] Q. He, H. Xie, Z. U. Rehman, C. D. Wang, P. Wan, H. L. Jiang, W. S. Chu, L. Song, ACS Energy Lett., 2018, 3, 861-868.

[13] C. Guan, H. J. Wu, W. Xiao, X. M. Liu, W. J. Zang, H. Zhang, J. Ding, Y. P. Feng, S. J. Pennycook, J. Wang, Nano Energy, 2018, 48, 73-80.

[14] B. W. Zhang, Y. H. Lui, A. P. S. Gaur, B. L. Chen, X. H. Tang, Z. Y. Qi, S. $\mathrm{Hu}$, ACS Appl. Mater. Interfaces, 2018, 10, 8739-8748.

[15] Q. Qin, H. Jang, P. Li, B. Yuan, X. E. Liu, J. Cho, Adv. Energy Mater. 2018, 9, 1803312.

[16] P. Z. Chen, K. Xu, Z. W. Fang, Y. Tong, J. C. Wu, X. L. Lu, X. Peng, H. Ding, C. Z. Wu, Y. Xie, Angew. Chem. Int. Ed., 2015, 54, 14710-14714.

[17] B. Q. Li, S. Y. Zhang, C. Tang, X. Y. Cui, Q. Zhang, Small, 2017, 13, 1700610.

[18] Y. X. Li, J. Yin, L. An, M. Lu, K. Sun, Y. Q. Zhao, F. Y. Cheng, P. X. Xi, Nanoscale, 2018, 10, 6581-6588.

[19] J. W. Li, Q. N. Zhuang, P. M. Xu, D. W. Zhang, L. C. Wei, D. S. Yuan, Chin. J. Catal., 2018, 39, 1403-1410.

[20] J. Jin, J. Yin, H. W. Liu, P. X. Xi, Chin. J. Catal., 2019, 40, 43-51.

[21] Y. S. Du, G. Z. Cheng, W. Luo, Nanoscale, 2017, 9, 6821-6825.

[22] C. Xia, Q. Jiang, C. Zhao, M. N. Hedhili, H. N. Alshareef, Adv. Mater., 2016, 28, 77-85.

[23] G. L. Chai, K. P. Qiu, M. Qiao, M. M. Titirici, C. X. Shang, Z. X. Guo, Energy Environ. Sci., 2017, 10, 1186-1195.

[24] B. S. Yeo, A. T. Bell, J. Am. Chem. Soc., 2011, 133, 5587-5593.

[25] K. W. Liu, C. L. Zhang, Y. D. Sun, G. H. Zhang, X. C. Shen, F. Zou, H. C. Zhang, Z. W. Wu, E. C. Wegener, C. J. Taubert, J. T. Miller, Z. M. Peng, Y. Zhu, ACS Nano, 2018, 12, 158-167.

[26] X. F. Lu, L. F. Gu, J. W. Wang, J. X. Wu, P. Q. Liao, G. R. Li, Adv. Mater., 2017, 29, 1604437.

[27] P. Pei, Z. F. Tian, Y. F. Zhu, Microporous Mesoporous Mater., 2018 $272,24-30$.

[28] L. K. Meng, K. Liu, S. Fu, L. Wang, C. Liang, G. H. Li, C. G. Li, Z. Shi, J. Solid State Chem., 2018, 265, 285-290.

[29] J. N. Joshi, G. H. Zhu, J. J. Lee, E. A. Carter, C. W. Jones, R. P. Lively, K. S. Walton, Langmuir, 2018, 34, 8443-8450.

[30] R. Yan, Y. Zhao, H. Yang, X. J. Kang, C. Wang, L. L. Wen, Z. D. Lu, $A d v$ Funct. Mater., 2018, 28, 1802021.

[31] M. Sohail, M. Altaf, N. Baig, R. Jamil, M. Sher, A. Fazal, New J. Chem. 2018, 42, 12486-12491.

\section{Graphical Abstract}

Chin. J. Catal., 2019, 40: 1205-1211 doi: S1872-2067(19)63384-X

\section{Cobalt/iron bimetal-organic frameworks as efficient electrocatalysts for the oxygen evolution reaction}

Shili Xie, Fei Li *, Suxian Xu, Jiayuan Li, Wei Zeng *

Dalian University of Technology;

Dalian Wondersun Biochemical Technology Co., LTD

Co/Fe-based bimetal-organic frameworks were synthesized, using a facile ultrasonic method, as efficient electrocatalysts for the OER. The optimized $\mathrm{Co}_{2} \mathrm{Fe}-\mathrm{MOF}$ exhibited high performance toward the OER.

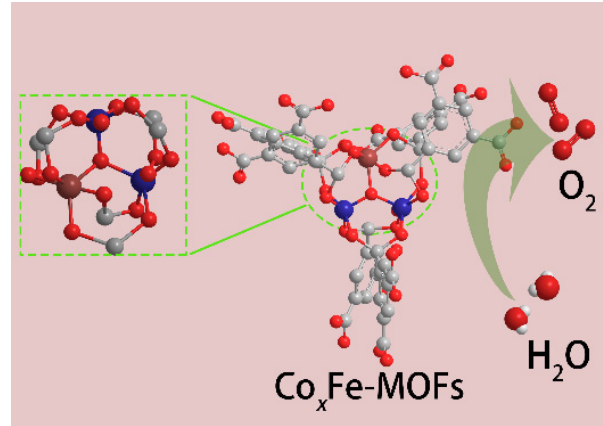


[32] X. Wang, L. Yu, B. Y. Guan, S. Y. Song, X. W. Lou, Adv. Mater., 2018, 30, 1801211.

[33] X. L. Wang, H. Xiao, A. Li, Z. Li, S. J. Liu, Q. H. Zhang, Y. Gong, L. R. Zheng, Y. Q. Zhu, C. Chen, D. S. Wang, Q. Peng, L. Gu, X. D. Han, J. Li, Y. D. Li, J. Am. Chem. Soc., 2018, 140, 15336-15341.

[34] L. M. Cao, Y. W. Hu, S. F. Tang, A. Lljin, J. W. Wang, Z. M. Zhang, T. B. Lu, Adv. Sci., 2018, 5, 1800949.

[35] M. M. Wang, M. T. Lin, J. T. Li, L. Huang, Z. C. Zhuang, C. Lin, L. Zhou, L. Q. Mai, Chem. Commun., 2017, 53, 8372.

[36] S. L. Zhao, Y. Wang, J. C. Dong, C. T. He, H. J. Yin, P. F. An, K. Zhao, X. F. Zhang, C. Gao, L. J. Zhang, J. W. Lv, J. X. Wang, J. Q. Zhang, A. M. Khattak, N. A. Khan, Z. X. Wei, J. Zhang, S. Q. Liu, H. J. Zhao, Z. Y. Tang, Nature Energy, 2016, 1, 16184.

[37] D. A. Yang, H. Y. Cho, J. Kim, S. T. Yang, W. S. Ahn, Energy Environ. Sci., 2012, 5, 6465-6473.
[38] X. J. Zheng, X. Y. Song, X. M. Wang, Z. H. Zhang, Z. M. Sun, Y. S. Guo, New J. Chem., 2018, 42, 8346-8350.

[39] F. Z. Sun, G. Wang, Y. Q. Ding, C. Wang, B. B. Yuan, Y. Q. Lin, Adv. Energy Mater., 2018, 8, 1800584.

[40] X. P. Dai, M. Z. Liu, Z. Z. Li, A. X. Jin, Y. D. Ma, X. L. Huang, H. Sun, H. Wang, X. Zhang, J. Phys. Chem. C, 2016, 120, 12539-12548.

[41] P. Guo, J. Wu, X. B. Li, J. Luo, W. M. Lau, H. Liu, X. L. Sun, L. M. Liu, Nano Energy, 2018, 47, 96-104.

[42] H. Wang, F. X. Yin, G. R. Li, B. H. Chen, Z. Q. Wang, Int. J. Hydrogen Energy, 2014, 39, 16179-16186.

[43] S. H. Liu, Z. Y. Wang, S. Zhou, F. J. Yu, M. Z. Yu, C. Y. Chiang, W. Z. Zhou, J. J. Zhao, J. S. Qiu, Adv. Mater., 2017, 29, 1700874.

[44] J. Zhou, Y. B. Dou, A. W. Zhou, R. M. Guo, M. J. Zhao, J. R. Li, Adv. Energy Mater., 2017, 7, 1602643.

\title{
钴/铁双金属有机框架材料用于电催化析氧反应
}

\author{
谢士礼 ${ }^{\mathrm{a}}$, 李 斐 ${ }^{\mathrm{a},{ }^{*}}$, 许素显 ${ }^{\mathrm{a}}$, 李佳原 ${ }^{\mathrm{a}}$, 曾 伟, ${ }^{\mathrm{b}, \#}$ \\ ${ }^{\mathrm{a}}$ 大连理工大学精细化工国家重点实验室, 辽宁大连 116024 \\ ${ }^{\mathrm{b}}$ 大连韦德生化科技有限公司, 辽宁大连 116600
}

\begin{abstract}
摘要: 开发高效且稳定的电催化剂用于水氧化反应对于能源存储与转化系统至关重要. 目前商业贵金属材料 $\left(\right.$ 如 $\mathrm{IrO}_{2}$ 和 $\mathrm{RuO}_{2}$ )拥有最好的电催化析氧性能, 但其稀缺性和高成本阻碍了它们的实际应用. 金属有机框架材料(MOFs)由于具有比表 面积大、周期性结构、孔径可调、金属中心和有机配体多样性等特点, 已经广泛应用于药物输送、气体存储、催化、传感 等领域. 在电催化领域, MOFs通常作为前驱体或模板在高温下热解来制备金属氧化物/多孔碳复合材料, 虽然它们显示出 较高的催化活性, 但是往往需要复杂的制备工艺和高温条件. 因此, 利用MOFs的固有活性不经过热解处理直接使用MOFs 作为析氧反应(OER)电催化剂是非常有意义的. 由于氧化态的钴中心有利于 $\mathrm{OOH}$ 物种的形成并可促进 $\mathrm{OOH}$ 脱质子形成氧 气, 钴基材料已经显示出很好的OER 性能. 尤其是当Fe掺杂进钴基催化剂时, OER性能可得到进一步提高. 因此, 开发一种 高效的 $\mathrm{Co} / \mathrm{Fe}$ 双金属MOFs 用于电催化析氧反应是很好的选择.

本文以 $\mathrm{Co}^{2+}$ 和 $\mathrm{Fe}^{3+}$ 为金属离子, 以均苯三甲酸为有机配体, 在三乙胺存在条件下通过简单的超声法合成了一系列不同 $\mathrm{Co} / \mathrm{Fe}$ 比的双金属MOFs. 以电催化性能最好的 $\mathrm{Co}_{2} \mathrm{Fe}-\mathrm{MOF}$ 为研究对象, 从扫描电子显微镜和透射电子显微镜图可以看出 $\mathrm{Co}_{2} \mathrm{Fe}-\mathrm{MOF}$ 由松散堆积的纳米粒子组成, 这种结构具有较大的比表面积, 从而可以暴露更多的催化活性位点. 电化学测试 结果表明, 在所有的 $\mathrm{Co}_{x} \mathrm{Fe}-\mathrm{MOFs}$ 中, $\mathrm{Co}_{2} \mathrm{Fe}-\mathrm{MOF}$ 达到 $10 \mathrm{~mA} \mathrm{~cm}{ }^{-2}$ 的电流密度需要的过电位 $(280 \mathrm{mV})$ 最低, 且低于大部分文

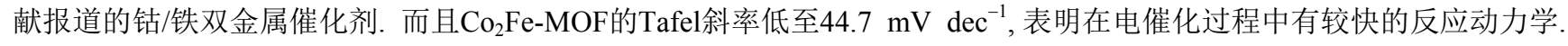
电化学阻抗分析表明, $\mathrm{Co}_{2} \mathrm{Fe}-\mathrm{MOF}$ 有较小的电荷转移电阻, 有利于电子从电解液到电极表面的传递. XPS测试分析表明, $\mathrm{Fe}$ 的加入可以调节 $\mathrm{Co}$ 金属中心周围的电子环境, 有利于提升催化剂的电催化性能. 总之, $\mathrm{Co}_{2} \mathrm{Fe}-\mathrm{MOF}$ 优良的电催化性能可归 因于其具有较大的比表面积、较高的电子传输速率以及 $\mathrm{Co}$ 和 $\mathrm{Fe}$ 金属中心的协同效应. 本研究为直接利用 $\mathrm{MOFs}$ 材料作为低 成本析氧反应电催化剂提供了新策略.
\end{abstract}

关键词: 双金属有机框架材料; 析氧反应; 电催化剂; 协同效应; 超声法

收稿日期: 2019-03-14. 接受日期: 2019-04-19. 出版日期: 2019-08-05.

*通讯联系人. 电话: (0411)84986247; 传真: (0411)84986245; 电子信箱: lifei@dlut.edu.cn

\#通讯联系人. 电话: (0411)88165993; 传真: (0411)88165911; 电子信箱: zeng_wei@wdspharma.com

基金来源：国家自然科学基金(21872016); 中央高校基本科研业务费专项资金(DUT17ZD204).

本文的电子版全文由Elsevier出版社在ScienceDirect上出版(http://www.sciencedirect.com/science/journal/18722067). 